Cell culture cortisol fetus lung maturation, fetal oxidant stress oxygen tension

Respiratory Distress Syndrome saturated phosphatidyl choline type II pneumocyte

\title{
Human Fetal Lung Type II Pneumonocytes in Monolayer Cell Culture: The Influence of Oxidant Stress, Cortisol Environment, and Soluble Fibroblast Factors
}

\author{
A. KEITH TANSWELL and BARRY T. SMITH
}

Department of Paediatrics, Queen's University, Kingston, Ontario, Canada

\begin{abstract}
Summary
A pure culture of human fetal lung type II pneumonocytes has been developed and labeled HFLP. Cells were studied during the period of exponential growth that was observed to occur in this system from day 4 to day 8 after subculture. Correlations with exponential growth were highly significant $(P<0.001)$ in all groups studied. Growth was not greatly different at any of the different oxygen tensions $(30,55,80$, and $145 \mathrm{~mm} \mathrm{Hg}$ ) examined except that growth was slightly more rapid at a $\mathrm{PO}_{2}$ of $145 \mathrm{~mm}$ $\mathrm{Hg}$ than at a $\mathrm{PO}_{2}$ of $80 \mathrm{~mm} \mathrm{Hg}(P<0.05)$. The uptake of ${ }^{3} \mathrm{H}$ choline into DSPC at a $\mathrm{PO}_{2}$ of $30 \mathrm{~mm} \mathrm{Hg}$ was significantly less than at $55 \mathrm{~mm} \mathrm{Hg}(P<0.001)$ or $80 \mathrm{~mm} \mathrm{Hg}(P<0.001)$, whereas the uptake at $145 \mathrm{~mm} \mathrm{Hg}$ was also significantly less than that at $55 \mathrm{~mm} \mathrm{Hg}(P<0.001)$ or $80 \mathrm{~mm} \mathrm{Hg}(P<0.001)$. Uptake at 55 and $90 \mathrm{~mm} \mathrm{Hg}$ was not significantly different. The response to added cortisol $(1 \mu \mathrm{M})$ also varied with the oxygen tension, with no effect at a $\mathrm{PO}_{2}$ of $30 \mathrm{~mm} \mathrm{Hg}$ while, at a $\mathrm{PO}_{2}$ of $55 \mathrm{~mm} \mathrm{Hg}$ the ${ }^{3} \mathrm{H}$ choline uptake was significantly different on day $5(P<0.001)$, day $6(P<0.001)$ and day $7(P<0.01)$. Similarly, at a $\mathrm{PO}_{2}$ of 80 $\mathrm{mm} \mathrm{Hg}$ the difference was significant on day $5(P<0.05)$, day 6 $(P<0.01)$ and day $7(P<0.01)$. At a $\mathrm{PO}_{2}$ of $145 \mathrm{~mm} \mathrm{Hg}$, the difference was just significant on day $7(P<0.05)$. In isolated HFLP cells, an oxidant challenge produced by increasing $\mathrm{PO}_{2}$ from 30 to $55 \mathrm{~mm} \mathrm{Hg}$ resulted in a $96 \%$ increase in ${ }^{3} \mathrm{H}$-choline uptake in both the control group $(P<0.001)$ and the steroid-added group $(P<0.001)$. In the combined HFLP and fetal lung fibroblast culture there was a $275 \%$ increase over the uptake before oxidant challenge after 48 hr (control group $P<0.001$, steroid group $P<$ $0.001)$. In the experiment where HFLP cells were grown in the presence of $10 \%$ fibroblast-derived medium, the increase after 48 hr was $135 \%$ over values before the oxidant challenge (control group $P<0.001$ ). In this experiment, the steroid-added group had an increased response compared to the control group $48 \mathrm{hr}$ after the oxidant challenge $(P<0.02)$.
\end{abstract}

\section{Speculation}

It was speculated that the type II pneumonocyte requires an unknown cofactor in order to respond to antenatal steroid treatment by increased production of surface active materials. It was further speculated that the change of $\mathrm{PO}_{2}$ that occurs in pulmonary tissue after delivery acts as an important biologic stimulus to cause increased production of surface active materials, and that this mechanism can be favorably enhanced by pretreatment with steroids, and is mediated in part by soluble factor(s) derived from the fetal lung fibroblast.

Development of the human fetal lung in utero occurs at a low oxygen tension $\left(\mathrm{PO}_{2}\right)$. The fetal arterial $\mathrm{PO}_{2}$ is constant throughout gestation at $20-22 \mathrm{~mm} \mathrm{Hg}$, which increases in the neonate after delivery at term to $100 \mathrm{~mm} \mathrm{Hg}$ by $24 \mathrm{hr}$ of age (17). This acute increase represents an oxidant stress that is well tolerated, without clinical disturbance, in full gestation infants. In the premature infant, however, in whom inadequate production of surface-active materials (SAM) by the type II pneumonocyte (7) has resulted in the Respiratory Distress Syndrome (RDS), survival may depend in part upon an adequate increase in intracellular oxygen-protective enzymes in the face of the oxidant challenge of delivery and oxygen therapy (4).

Alterations of $\mathrm{PO}_{2}$ of this magnitude can influence growth $(6,24)$ and biologic activity $(15,24)$ in some cell types. The influence of differing oxygen tensions upon growth and incorporation of choline into saturated phosphatidylcholine (DSPC), a major functional component of the SAM in the neonatal lung (20), by isolated type II pneumonocytes grown in continuous monolayer cell culture have, therefore, been examined. The effect of pretreatment with cortisol before the oxidant stress has also been examined because this is a recognized form of therapy to enhance fetal lung maturation in premature fetuses likely to develop RDS (11). Steroids can enhance (1) or protect (2) against oxidant stress, though the effect of steroids in neonatal pulmonary oxygen toxicity is uncertain (23).

Lastly, the influence of fibroblasts and soluble fibroblast factors upon the changes in choline incorporation into DSPC by the type II pneumonocyte exposed to oxidant stress has been studied.

\section{MATERIALS AND METHODS}

The experimental techniques described in this paper are essentially similar to those developed for the study of oxidant stress upon growth and biological activity of the fetal lung fibroblast (24).

Eagle's minimal essential tissue culture medium with Earle's salts (32) was supplemented with $10 \%$ fetal calf serum (33) and antibiotics (21). This preparation will subsequently be called "tissue culture medium." The fetal calf serum provides the tissue culture medium with traces $(1.4 \mathrm{~nm})$ of cortisol (21). A buffered trypsin-EDTA solution containing $0.5 \mathrm{~g}$ trypsin $1: 250$ and $2.0 \mathrm{~g}$ EDTA/liter (32) was used for cell dispersal (21). Plastic tissue culture flasks with a surface area of $75 \mathrm{~cm}^{2}$ (34) were used to maintain the cultures and flasks with a surface area of $25 \mathrm{~cm}^{2}(34)$ were used for experimental periods. The tissue culture medium containing cortisol $(1 \mu \mathrm{M})$ was made up as described previously (19).

The type II pneumonocyte line used in these studies was developed in this laboratory, and has been labeled HFLP. Lung tissue was taken at autopsy from a 36-wk-gestation anencephalic fresh stillbirth, and developed into a mixed lung cell culture by established techniques (21). During the course of another experiment 
with this culture (19), a dilute suspension of the culture was distributed on a cloning plate to give a theoretical cell count of one cell in each cloning well. On microscopy, some wells were found to contain single cells whereas others contained two or more. From one of the single cell wells was derived the pure fetal lung fibroblast culture (labeled KGH 9L) used in this experiment (24), and from one of the wells containing two cells was developed a mixed cell line which contained only fibroblasts and type II pneumonocytes. Because these two cell types separate at different rates from the culture flask surface in the presence of trypsin, it was possible to develop a pure type II cell line from a low density suspension at low oxygen tensions. Chromosomal analysis of HFLP cells shows a diploid configuration and electron-microscopy reveals the characteristic lamellar bodies of the type II pneumonocyte. A detailed account of the isolation technique and the cell morphology will be published separately.

Cultures were maintained as described previously (24) under a variety of gases containing 5\% carbon dioxide, nitrogen, and various oxygen concentrations. During this equilibration period, the gas and medium were changed daily. The medium used had also been equilibrated in a glass vessel, to prevent gas diffusion, for 2-3 wk with the particular gas being used. For experimental periods, three large flasks had their cells dispersed into a common mixing chamber followed by redistribution of a roughly equal number of cells into 40 small flasks. To half, cortisol $(1 \mu \mathrm{M})$ was introduced the day after subculture, and all had the medium and gas changed each day.

Cell numbers were studied during the period of exponential growth that had been observed in preliminary work with this system to occur from day 4 to day 8 . Cell numbers before this are affected by losses secondary to dispersal and subculture (27) and may have reduced levels of intracellular oxygen protective enzymes due to contact with trypsin (30). After this time, some flasks showed evidence of confluence that inhibits growth and is associated with alterations of cell metabolism (10). Once metabolic studies had been performed, the cells were trypsinized, diluted, and counted (24). Five flasks were counted on each day for both the steroid-added and the control groups, allowing the calculation of doubling times for each of the oxygen concentrations studied.

Cells in each flask were incubated in the flask for $3 \mathrm{hr}$ at $37^{\circ} \mathrm{C}$ with $5 \mathrm{ml}$ Earle's balance salt solution (32) containing $1.6 \mu \mathrm{Ci} / \mathrm{ml}$ [methyl- ${ }^{3} \mathrm{H}-$ ] choline chloride (New England Nuclear, Lot number 990-207, specific activity $69.5 \mathrm{Ci} / \mathrm{mmole}$ ). The uptake of ${ }^{3} \mathrm{H}$ choline into DSPC was estimated according to the method of Mason et al. (12) as described previously (20). Isotope counting was performed in a Searle Isocap 300 liquid scintillation spectrophotometer and the results are expressed as $\mathrm{cpm} / 10^{3}$ cells. Uptake reduced slightly with each successive day of exponential growth, but increased markedly at confluence to 3-4 times that seen during exponential growth. It was preferred, however, to examine the cells during exponential growth because this may mimic the situation in utero, and because the metabolic disturbances that occur at confluence could influence results. In the metabolic studies, $1 \mu \mathrm{M}$ cortisol was introduced on day 4 after subculture.

Cells were allowed the prolonged equilibration period with the study gases to allow intracellular oxygen protective enzymes to equilibrate with the selected oxygen tensions (18). On days 4 and 7 after subculture, 10 flasks were analyzed for $\mathrm{PO}_{2}, \mathrm{PCO}_{2}$, and $\mathrm{pH}$ immediately before, and $1 \mathrm{hr}$ after, gas change. Analyses were made with a Radiometer BMS Mk 2 blood microsystem. The mean results of these values for each of the gas mixtures used are shown in Table 1.

Having examined cells adapted to the various oxygen concentrations, the effect of acute moderate oxidant stress upon the cells by suddenly increasing the $\mathrm{PO}_{2}$ from $30.46 \pm 3.7$ to $55.10 \pm 5.7$ $\mathrm{mm} \mathrm{Hg}$ was examined. The uptake of ${ }^{3} \mathrm{H}$-choline into DSPC by HFLP alone was examined; also examined were the uptakes by HFLP with KGH 9L where the original subculture contained equal numbers of both, and by HFLP grown in tissue culture medium of which $10 \%$ was cell-free medium derived from cultured $\mathrm{KGH}$ 9L fibroblasts. In these experiments, the cortisol-added medium was not introduced until 24 or $48 \mathrm{hr}$ before the oxidant stress.

Results for cell number and ${ }^{3} \mathrm{H}$-choline uptake into DSPC were available from 10 flasks each day, of which half contained cortisol (1 $\mu \mathrm{M})$. From this data, means and SE for each group were calculated on each day. For the cells equilibrated with the four gases, exponential growth curves could be calculated that gave the doubling time in each gas, and also correlation coefficients for exponential growth in each gas. By using the logarithmic value for each cell count a linear regression for cell growth was derived that could then be compared (25) using Student's $t$ test. Values for ${ }^{3} \mathrm{H}$-choline incorporation in each group were also compared using Student's $t$ test.

\section{RESULTS}

Doubling times and correlation coefficients for exponential growth of HFLP equilibrated with various oxygen tensions are shown in Table 2 . Correlation with exponential growth was highly significant $(P<0.001)$ in all groups. In none of the oxygen tensions examined did the addition of cortisol $(1 \mu \mathrm{M})$ significantly affect growth rate, nor was growth greatly different in any of the different oxygen tensions, though growth was slightly more rapid in the control group in a $\mathrm{PO}_{2}$ of $145 \mathrm{~mm} \mathrm{Hg}$ than at $80 \mathrm{~mm} \mathrm{Hg}$ $(\mathrm{t}=2.30, \mathrm{df}=38, P<0.05)$.

In contrast, however, are the differences observed in ${ }^{3} \mathrm{H}$-choline incorporation into DSPC by HFLP equilibrated with the various oxygen tensions as shown in Figure 1 . At a $\mathrm{PO}_{2}$ of $30 \mathrm{~mm} \mathrm{Hg}$, uptake of ${ }^{3} \mathrm{H}$-choline is significantly less than at a $\mathrm{PO}_{2}$ of $55 \mathrm{~mm}$ $\mathrm{Hg}(\mathrm{t}=4.75, \mathrm{df}=38, P<0.001)$, or of $80 \mathrm{~mm} \mathrm{Hg}(\mathrm{t}=6.95$, df $=38, P<0.001$ ), whereas the uptake at $145 \mathrm{~mm} \mathrm{Hg}$ is also significantly less than that at $55 \mathrm{~mm} \mathrm{Hg}(\mathrm{t}=5.56, \mathrm{df}=38, P<$ $0.001)$ or $80 \mathrm{~mm} \mathrm{Hg}(\mathrm{t}=7.65, \mathrm{df}=38, P<0.001)$. Uptake at 55 and $80 \mathrm{~mm} \mathrm{Hg}$ is not significantly different $\mathrm{t}=1.79, \mathrm{df}=38, P$ $=$ N.S.).

The response to added cortisol $(1 \mu \mathrm{M})$ also varies with the oxygen tension. There is no effect at a $\mathrm{PO}_{2}$ of $30 \mathrm{~mm} \mathrm{Hg}(\mathrm{t}=0.09$, $\mathrm{df}=33, P=$ N.S.) whereas at a $\mathrm{PO}_{2}$ of $55 \mathrm{~mm} \mathrm{Hg}{ }^{3} \mathrm{H}$-choline uptake is significantly different on day $5(\mathrm{t}=5.75$, df $=8, P<$ $0.001)$, day $6(\mathrm{t}=6.03, \mathrm{df}=8, P<0.001)$, and day $7(\mathrm{t}=4.41$, df

Table I. Acid base data: Shown are the mean values for $\mathrm{PO}_{2}$, $\mathrm{PCO}_{2}$ and $\mathrm{pH}$ obtained in the culture medium during exponential growth of HFLP over four days under gases containing four different oxygen concentrations

\begin{tabular}{cccc}
\hline & \multicolumn{3}{c}{ Medium } \\
\cline { 2 - 4 } Gas & $\begin{array}{c}\mathrm{PO}_{2} \mathrm{~mm} \mathrm{Hg} \\
(\mathrm{M} \pm \mathrm{SD})\end{array}$ & $\begin{array}{c}\mathrm{PCO}_{2} \mathrm{~mm} \mathrm{Hg} \\
(\mathrm{M} \pm \mathrm{SD})\end{array}$ & $\begin{array}{c}\mathrm{pH} \\
(\mathrm{M} \pm \mathrm{SD})\end{array}$ \\
\hline $0.95 \% \mathrm{O}_{2}: 5 \% \mathrm{CO}_{2}:$ Ball. $_{2}$ & $30.46 \pm 3.7$ & $45.4 \pm 2.8$ & $7.23 \pm 0.09$ \\
$4 \% \mathrm{O}_{2}: 5 \% \mathrm{CO}_{2}:$ Bal. $_{2}$ & $55.10 \pm 5.7$ & $46.9 \pm 4.3$ & $7.24 \pm 0.09$ \\
$10 \% \mathrm{O}_{2}: 5 \% \mathrm{CO}_{2}:$ Bal. $_{2}$ & $79.98 \pm 4.2$ & $47.3 \pm 3.9$ & $7.22 \pm 0.05$ \\
$20 \% \mathrm{O}_{2}: 5 \% \mathrm{CO}_{2}:$ Bal. $_{2}$ & $145.31 \pm 8.6$ & $46.8 \pm 5.0$ & $7.20 \pm 0.11$ \\
\hline
\end{tabular}

Table 2. Cell growth at different oxygen tensions: Doubling times for HFLP grown in four different oxygen tensions, with or without added cortisol

\begin{tabular}{|c|c|c|c|c|}
\hline \multirow[b]{2}{*}{$\begin{array}{c}\mathrm{PO}_{2} \mathrm{~mm} \mathrm{Hg} \\
(\mathrm{M} \pm \mathrm{SD})\end{array}$} & \multicolumn{2}{|c|}{ Control } & \multicolumn{2}{|c|}{$+1 \mu \mathrm{M}$ cortisol } \\
\hline & $\begin{array}{c}\text { Exponential } \\
\text { growth }^{1}\end{array}$ & $\begin{array}{l}\text { Doubling } \\
\text { time (hr) }\end{array}$ & $\begin{array}{c}\text { Exponential } \\
\text { growth }\end{array}$ & $\begin{array}{l}\text { Doubling } \\
\text { time (hr) }\end{array}$ \\
\hline $30.46 \pm 3.7$ & $r=0.968$ & 28.98 & $r=0.971$ & 28.41 \\
\hline $55.10 \pm 5.7$ & $r=0.972$ & 28.50 & $r=0.981$ & 29.73 \\
\hline $79.98 \pm 4.2$ & $r=0.970$ & 31.20 & $r=0.960$ & 29.95 \\
\hline $145.31 \pm 8.6$ & $r=0.977$ & 26.94 & $r=0.920$ & 28.16 \\
\hline
\end{tabular}

' $r$ is the correlation coefficient for exponential growth of each growtl curve. 
$=8, P<0.01)$. Similarly, at a $\mathrm{PO}_{2}$ of $80 \mathrm{~mm} \mathrm{Hg}$, the difference is significant on day $5(\mathrm{t}=2.67, \mathrm{df}=8, P<0.05)$, day $6(\mathrm{t}=3.79$, $\mathrm{df}=8, P<0.01)$, and day $7(\mathrm{t}=3.6, \mathrm{df}=8, P<0.01)$. At a $\mathrm{PO}_{2}$ of $145 \mathrm{~mm} \mathrm{Hg}$, the difference is not significant on day $5(\mathrm{t}=1.23$, $\mathrm{df}=8, P=\mathrm{N}$.S. $)$ or day $6(\mathrm{t}=2.18, \mathrm{df}=8, P=\mathrm{N} . \mathrm{S}$. $)$ and is just significant on day $7(\mathrm{t}=2.84, \mathrm{df}=8, P<0.05)$.

The results of the acute oxidant stress $\left(\mathrm{PO}_{2}\right.$ increased from 30 $55 \mathrm{~mm} \mathrm{Hg}$ ) experiments are shown in Figure 2. For the isolated HFLP, the oxidant challenge resulted in a $96 \%$ increase in ${ }^{3} \mathrm{H}$ -

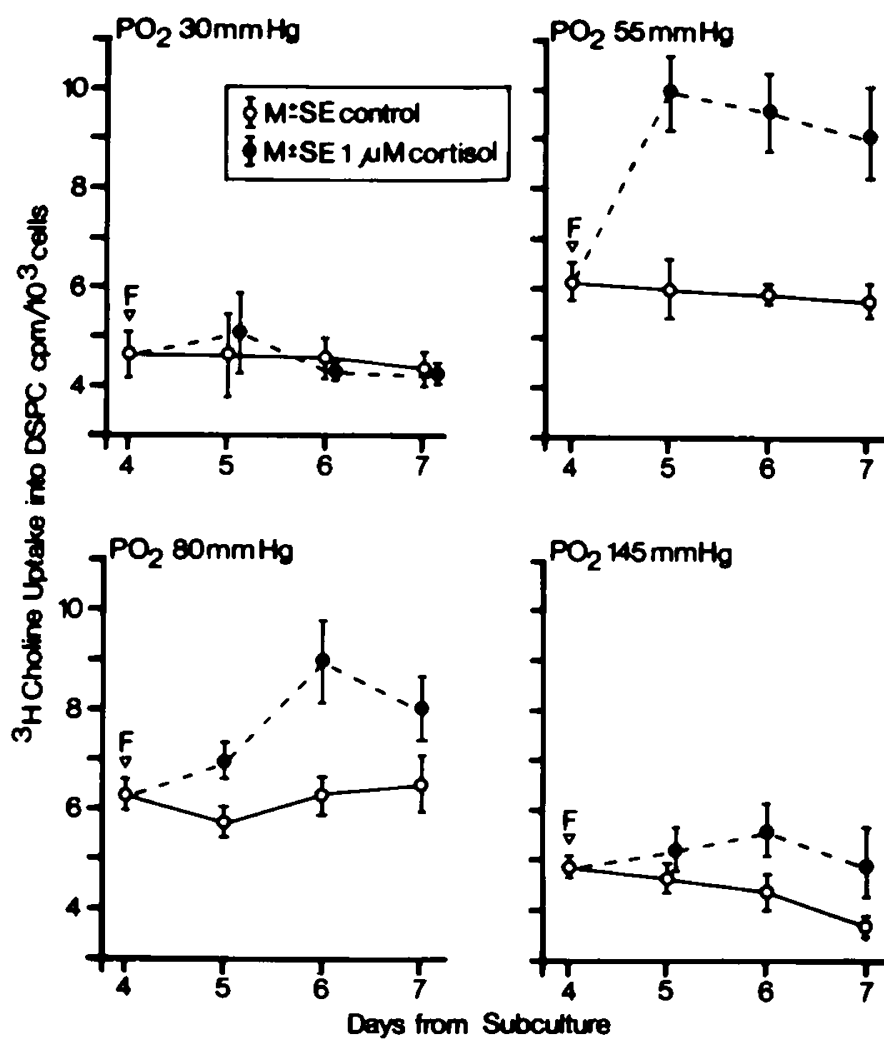

Fig. 1. The influence of cortisol at different oxygen tensions upon ${ }^{3} \mathrm{H}-$ choline incorporation by HFLP is shown. Cell line HFLP adapted to four different oxygen tensions in exponential growth. This figure shows the uptake of ${ }^{3} \mathrm{H}$-choline into DSPC on days 4-7 from subculture in controls and in cells incubated with $1 \mu \mathrm{M}$ cortisol (F) added on day 4. Each point represents the mean of five observations. choline uptake in both the control group $(\mathrm{t}=5.55, \mathrm{df}=8, P<$ $0.001)$ and the steroid-added group $(\mathrm{t}=5.66, \mathrm{df}=8, P<0.001)$. In this experiment, the addition of cortisol $(1 \mu \mathrm{M})$ resulted in a fall in uptake $(\mathrm{t}=4.55, \mathrm{df}=8, P<0.01)$. This experiment has been repeated several times and the cortisol either produces a fall or has no effect, as in the equilibrated gas experiments. In the combined HFLP and KGH 9L culture, there was a significant reduction of activity $24 \mathrm{hr}$ after the oxidant challenge in both groups (control group; $\mathrm{t}=7.67, \mathrm{df}=8, P<0.001$ ): steroid group; $\mathrm{t}=4.15, \mathrm{df}=8, P<0.01$ ) followed at $48 \mathrm{hr}$ by a $275 \%$ increase over the uptake before oxidant challenge (control group; $\mathrm{t}=12.23$, $\mathrm{df}=8, P<0.001$ : steroid group; $\mathrm{t}=14.39, \mathrm{df}=8, P<0.001$ ). In this mixed cell culture the control group had a greater response than the steroid group $(\mathrm{t}=4.58, \mathrm{df}=8, P<0.01)$, though this is difficult to interpret because $\mathrm{KGH} 9 \mathrm{~L}$ growth rates are affected by the addition of cortisol (24) and one cannot be certain that the proportion of the cells that are HFLP is the same in the two groups. In fact, it is unlikely that they are. Whatever the proportion, it is apparent that the increase of $275 \%$ is even greater when expressed in terms of ${ }^{3} \mathrm{H}$-choline uptake into DSPC $/ 10^{3} \mathrm{HFLP}$ cells. In the experiment where HFLP cells were grown in the presence of $10 \% \mathrm{KGH} 9 \mathrm{~L}$ derived medium, a significant reduction in uptake is seen in both groups $24 \mathrm{hr}$ after oxidant challenge (control group; $\mathrm{t}=7.65, \mathrm{df}=8, P<0.001$ : steroid group $\mathrm{t}=5.43$, $\mathrm{df}=8, P<0.001$ ) with an increase of $135 \%$ over values before the oxidant challenge after $48 \mathrm{hr}$ (control group; $\mathrm{t}=10.46, \mathrm{df}=8, P$ $<0.001$ : steroid group; $\mathrm{t}=17.72, \mathrm{df}=8, P<0.001$ ). In this experiment, the steroid added group has an increased response compared to the control group $48 \mathrm{hr}$ after the oxidant challenge $(\mathrm{t}=3.10, \mathrm{df}=8, P<0.02)$

\section{DISCUSSION}

Cell line HFLP offers certain advantages to the study of physiologic and pathologic oxidant stresses upon the fetal lung type II pneumocyte. It is not only a pure human line, but it is derived from a fetal source, an advantage because the young of a species is more resistant to oxygen toxicity than the adult and also primates are the most resistant of mammals (5). Its use in vitro provides the opportunity to study type II pneumocyte responses under a variety of controlled conditions and allows its interrelationships with other cells to be better defined. Its other advantage is that it is derived from a fetus of a gestational age at which RDS occurs.

The absence of growth rate differences in different oxygen tensions is contrary to the authors' experience with fetal lung

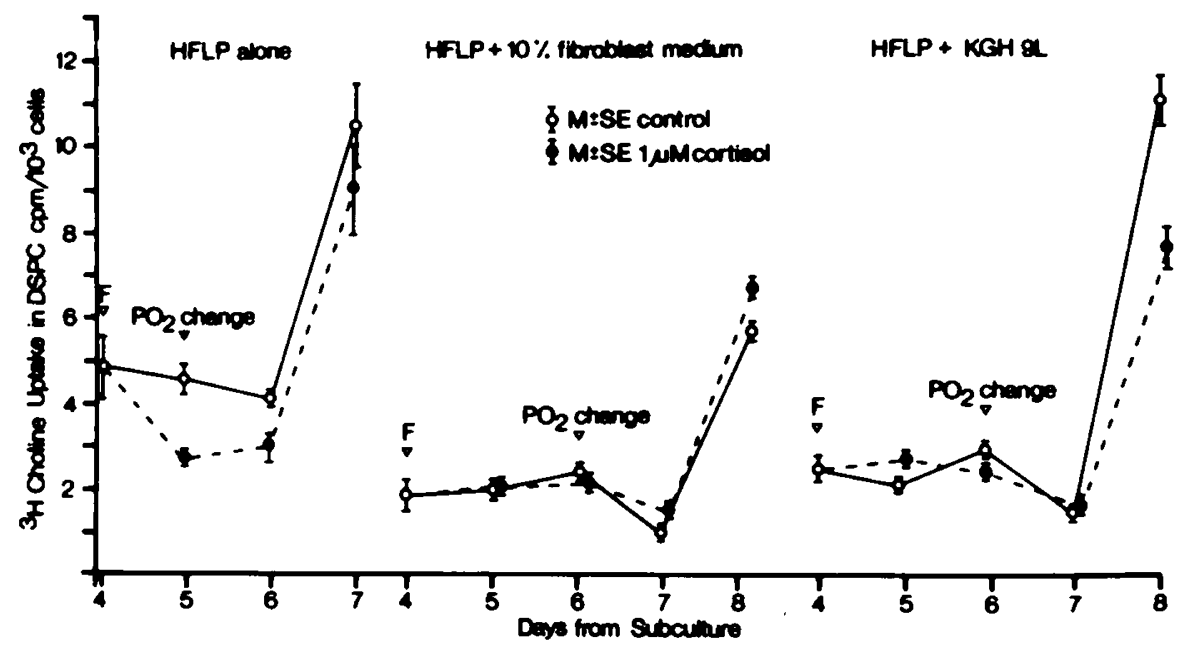

Fig. 2. The influence of oxidant stress, cortisol, and fibroblast factors upon ${ }^{3} \mathrm{H}$-choline incorporation by HFLP. Cell line HFLP alone, with $\mathrm{KGH} 9 \mathrm{~L}$, or with $\mathrm{KGH} 9 \mathrm{~L}$ derived medium in a $\mathrm{PO}_{2}$ of $30.46 \mathrm{~mm} \mathrm{Hg}$ exposed to an oxidant stress by a sudden increase of $\mathrm{PO}_{2}$ to $55.10 \mathrm{~mm} \mathrm{Hg}$.
Both control and cortisol-added groups were in exponential growth before the $\mathrm{PO}_{2}$ change. Cortisol $(\mathrm{F})$ was added at the points indicated by an arrow. Each point represents the mean of 5 observations. 
fibroblasts (24), and this difference may be explained by the difference in mitochondrial content of the two cell types which should favor the type II pneumocyte in terms of withstanding oxidant stresses (30). That its growth rate can vary under different oxygen tensions is clear, though these changes reflect the effect of acute alterations of oxygen tension (3). The experimental system described previously does not allow a sufficient time period to study oxidant induced changes of growth rate. These studies will be performed using larger cell culture flasks that give a greater time period before confluence occurs.

Experimental evidence suggests that maturation of the fetal lung in man $(14,22)$, as in animals $(8,9,28,29)$, is dependent upon its corticosteroid milieu. Glucocorticoids in the human fetus are predominantly in the biologically inactive 11 -ketosteroid form. The proportion of cortisol, the major component of the biologically active $11 \beta$-hydroxycorticosteroids, increases with gestation (13), though its origins are ill-defined (26). Exogenous steroids can enhance fetal lung maturation both in vivo (11), and in vitro (21). It was surprising, therefore, to see no response to steroids at a $\mathrm{PO}_{2}$ similar to that seen in utero, despite the cells' obvious ability to increase choline incorporation into DSPC in response to cortisol at higher oxygen tensions. This suggested that either exogenous steroids do not act directly upon the type II pneumonocyte, or more probably that there is some cofactor, missing from the cell culture model, which enhances the type II pneumonocytes' response at an intrauterine $\mathrm{PO}_{2}$.

The observations that an increase in oxygen tension from intrauterine levels results in increased choline incorporation into DSPC suggests that the alteration of intrapulmonary $\mathrm{PO}_{2}$ that occurs at delivery would act as one stimulus to increase SAM production. This is an attractive hypothesis in biologic terms because the fetus has no need of SAM in its fluid filled lungs, whereas SAM is obligatory with air breathing. It is interesting that the lag period before the oxidant challenge results in increased DSPC production is of the same order as that seen before infants with SAM deficiency (RDS) produce adequate quantities, and, thus, recover from the disease (7). Cortisol and other factors will already have increased SAM content in the airways of the mature fetus, allowing adequate quantities for the first breath and subsequent air breathing.

Whereas the addition of fibroblasts or fibroblast "factors" does not improve the steroid responsiveness of HFLP at a $\mathrm{PO}_{2}$ of 30 $\mathrm{mm} \mathrm{Hg}$, they markedly alter the response to oxidant stress. This supports our previous observations (19) that there are soluble fibroblast-derived factors which can influence the behavior of the type II pneumonocyte. The increase in ${ }^{3} \mathrm{H}$-choline incorporation into DSPC with oxidant challenge is very significant and when enhanced by the addition of fibroblast medium suggests that they may be a fibroblast-derived soluble mediator, and of particular interest is the observation that this enhancement is greater in cells pretreated with cortisol.

\section{REFERENCES AND NOTES}

1. Allen, J. E., Goodman, B. P., Besarab, A., and Rasmussen, H.: Studies on the biochemical basis of oxygen toxicity. Biochim. Biophys. Acta, 320: 708 (1973)

2. Alpert, S. M., Schwarz, B. B., Lee, S. D., and Lewis, T. R.: Alveolar protein accumulation. Arch. Intern. Med., 128: 69 (1971).

3. Bonikos, D. S., Bensch, K. G., Northway, W. H., and Edwards, D. K.: Bronchopulmonary dysplasia. The pulmonary pathological sequel of necrotizing bronchiolitis and pulmonary fibrosis. Human Pathol., 7: 643 (1976).

4. Bonta, B. W., Gawron, E. R., and Warshaw, J. B.: Neonatal red cell superoxide dismutrase enzyme levels: Possible role as a cellular defense mechanism against pulmonary oxygen toxicity. Pediatr. Res., 11: 754 (1977).

5. Clark, J. M., and Lambertson, C. J.: Pulmonary oxygen toxicity: A review. Pharmacol. Rev., 23: 37 (1971)

6. Cooper, P. D., Burt, A. M., and Wilson, J. N.: Critical effect of oxygen tension on rate of growth in animal cells in continuous suspended culture. Nature, 182: 1508 (1958).

7. Farrell, P. M., and Avery, M. E.: Hyaline membrane disease. Am. Rev. Respir Dis., 111: 657 (1975)

8. Farrell, P. M., Blackburn, W. R., and Adams, A. J.: Lung phosphatidylcholine synthesis and cholinephosphotransferase in anencephalic rat fetuses with corticosteroid deficiency. Pediatr. Res., 11: 770 (1977).

9. Giannopoulos, G.: Variations in the level of cytoplasmic glucocorticoid receptors in lungs of various species at different developmental stages. Endocrinology, 94: 450 (1974)

10. Kilburn, D. G., Lilly, M. D., Self, D. A., and Webb, F. C.: The effect of dissolved oxygen partial pressure on the growth and carbohydrate metabolism of mouse LS cells. J. Cell Sci., 4: 25 (1969).

11. Liggins, G. C., and Howie, R. N.: A controlled trial of antepartum glucocorticoid treatment for prevention of the respiratory distress syndrome in premature infants. Pediatrics, 50: 515 (1972)

12. Mason, R.. Nellenbogen, J., and Clements, J. A.: Isolation of disaturated phosphatidylcholine with osmium tetroxide. J. Lipid Res., 17: 281 (1976)

13. Murphy, B. E. P.: Does the human fetal adrenal play a role in parturition? Am. J. Obstet. Gynecol., 115: 521 (1973)

14. Murphy, B. E. P.: Evidence of cortisol deficiency at birth in infants with respiratory distress syndrome. J. Clin. Endocrinol. Metab., 38: 158 (1974).

15. Pawalek. J. M.: Effect of thyroxine and low oxygen tension on chondrogenic expression in cell culture. Dev. Biol., 19: 52 (1969).

16. Rosenbaum, R. M., Wittner, M., and Lenger, M.: Mitochondrial and other ultrastructural changes in great alveolar cells of oxygen-adapted and poisoned rats. Lab. Invest., 20: 516 (1969).

17. Rudolph, A. M.: In: Congenital Diseases of the Heart. (Year Book Medical Publishers, Inc., Chicago, 1974)

18. Simon, L. M., Liu, J., Theodore. J., and Robin, E. D.: Effect of hyperoxia, hypoxia, and maturation on superoxide dismutase activity in isolated alveolar macrophages. Am. Rev. Respir. Dis., 115: 279 (1977).

19. Smith, B. T.: Fibroblast-pneumonocyte factor: Intercellular mediator of glucocorticoid effect on fetal lung. In: L. Stern: Intensive Care in the Newborn (Masson, Boston, pp. 25-32).

20. Smith, B. T.: The role of pulmonary corticosteroid 11 -reductase activity in lung maturation in the fetal rat. Pediatr. Res., 12: 12 (1978).

21. Smith, B. T., Torday, J. C., and Giroud, C. J. P.: Evidence for different gestationdependent effects of cortisol on cultured fetal lung cells. J. Clin. Invest.. 53 : 1518 (1974).

22. Smith, B. T., Worthington, D., and Maloney, A. H. A.: Fetal lung maturation. The amniotic fluid cortisol/cortisone ratio in preterm human delivery and the risk of respiratory distress syndrome. Obstet. Gynecol., 49: 527 (1977).

23. Taeusch, H. W.: Glucocorticoid prophylaxis for respiratory distress syndrome. A review of potential toxicity. J. Pediatr., 87: 617 (1975)

24. Tanswell, A. K., and Smith, B. T.: Influence of oxygen tension and cortisol environment upon growth and cortisone conversion to cortisol by cultured human fetal lung fibroblasts. Biol. Neonat., (in press).

25. Tanswell. A. K., and Smith, B. T.: The relationship of amniotic membrane 11 oxidoreductase activity to lung maturation in the human fetus. Pediatr. Res., 12: 957 (1978)

26. Tanswell, A. K., Worthington, D., and Smith, B. T.: Human amniotic membrane corticosteroid 11-oxidoreductase activity. J. Clin. Endocrinol. Metab., 45: 721 (1977).

27. Taylor, W. G., Richter, A., Evans, V. J., and Sanford, K. K.: Influence of oxygen and $\mathrm{pH}$ on plating efficiency and colony development of WI 38 and Vero cells. Exptl. Cell Res., 86: 152 (1974)

28. Torday, J. S., Smith, B. T., and Giroud, C. J. P.: The rabbit fetal lung as a glucocorticoid target tissue. Endocrinology, 96: 1462 (1975).

29. Vidyasagar, D., and Chernick, V.: Effects of metopirone on the synthesis of lung surfactant in does and fetal rabbits. Biol. Neonat., 27: 1 (1975).

30. Yamanaka, N.. and Deamer, D.: Superoxide dismutase activity in W1 38 cell cultures: Effects of age, tripsinization, and SV 40 transformation. Physiol. Chem. Physics, 6: 95 (1974)

31. The abbreviations used are cortisol $11 \beta, 17 \alpha, 21$-trihydroxy pregn-4-ene-3,20dione.

32. Gibco Canada Ltd., Burlington, Ontario

33. Flow Laboratories, Rockville, MD

34. Corning Glassworks, Corning, NY

35. The authors thank W. Bogues, D. Minshall, J. Sahasra-Budhe, and E. Vreeken for expert technical assistance.

36. This research was supported by a grant (MA 5757) from the Medical Research Council of Canada.

37. Dr. A. K. Tanswell is a Fellow of the Canadian Cystic Fibrosis Foundation, and the W. T. McEachern Foundation.

38. Dr. B. T. Smith is a Scholar, Medical Research Council of Canada

39. Requests for reprints should be addressed to: Dr. A. K. Tanswell. Department of Paediatric Research, Queen's University, 146 Stuart Street, Kingston, Ontario K7L 3N6 (Canada).

40. Received for publication July 10, 1978

41. Accepted for publication October 9, 1978 